\title{
STUDI PRIVASI DAN AKSESIBILTAS DALAM RUMAH HUNIAN YANG MEMILIKI PONDOKAN MAHASISWA DITINJAU DARI NILAI-NILAI AS SUNNAH
}

\author{
NunikJunara dan Tarranita KusumaDewi \\ Fakultas Saintek Jurusan Arsitektur UIN Maliki Malang \\ email: nunikjunara@yahoo.com,tarra_nita@yahoo.com
}

\begin{abstract}
The existence of boarding house, the process of acculturation and values shift in residence, affect the physical and non-physical condition of the home and its surroundings. Similarly, shifting occurs in the private-public space caused by the interaction between the occupants. In a pluralistic Muslim society, the Islamic values influence the process of shifting the public-private space. Accessibility becomes the main concern in the shift pattern as a consequence of the limited land and increasing space demand. There are two shift patterns, physical shift indicating a change in the function space, and non-physical shift involving a sense of space for those interact in it. Sunnah values are employed to see the aspects are considered in home, especially on privacy and interaction. It used descriptive method through collecting detailed information that depicts the existing symptoms, identifying, making comparisons or evaluations and determining what is done to establish a plan or decision. The result of this study is the suggested design that can synergize with the activities occuring within it.
\end{abstract}

Keberadaan rumah pondokan mahasiswa, terjadinya proses akulturasi budaya dan pergeseran nilai-nilai dalam rumah hunian, mempengaruhi kondisi fisik dan non fisik rumah dan lingkungannya. Begitu pula terjadinya pergeseran ruang privat-publik pada rumah hunian yang disebabkan interaksi antara pemilik rumah dengan penghuni pondokannya. Dalam lingkungan masyarakat muslim yang majemuk terdapat nilai-nilai Islam yang mempengaruhi terjadinya proses pergeseran ruang privat-publik tersebut. Aksesibilitas merupakan hal utama yang harus diperhatikan pada pola pergeseran ruang sebagai konsekuensi sempitnya 
lahan dan bertambahnya kebutuhan ruang. Terdapat dua pola pergeseran ruang, pertama secara fisik yang mengindikasikan perubahan fungsi ruang, dan kedua secara non fisik, yang melibatkan rasa ruang dari pelaku-pelaku yang berinteraksi didalamnya. Nilai-nilai as Sunnah digunakan untuk mengkaji aspek-aspek yang dipertimbangkan dalam rumah tinggal terutama privasi dan interaksi. Adapun metode yang digunakan adalah deskriptif, dengan mengumpulkan informasi aktual secara rinci yang menggambarkan gejala-gejala yang ada, mengidentifikasi, membuat perbandingan atau evaluasi dan menentukan apa-apa yang dilakukan untuk menetapkan rencana atau keputusan. Hasil dari kajian ini berupa saran rancangan yang dapat bersinergi dengan aktivitas yang terjadi di dalamnya.

Keywords: privacy, accessibility, boarding house, sunnah values

\section{Pendahuluan}

Permukiman di kampung kota mempunyai segi-segi khusus dan spesifik yang diakibatkan oleh berbagai latar belakang sosial, ekonomi dan budaya para penghuninya yang saling terkait satu sama lain. Dalam seni bermukim, manusia diberi kelebihan dan keterbatasan dalam proses beradaptasi dengan lingkungannya. Kehidupan kampung yang ada di kota-kota besar sangat menarik untuk diamati, terutama terkait dengan aspek-aspek sosial, budaya dan ekonomi yang tumbuh dan berkembang seiring dengan perkembangan kota tersebut. Banyak hal yang telah dilakukan oleh masyarakat dalam kehidupan sehari-hari yang pada akhirnya membentuk suatu tatanan kehidupan khas kampung kota, baik dalam bentuk ruang maupun bangunan.

Hunian secara kuantitatif dan fisik diartikan sebagai sebuah ruang yang tertutup atap dengan luas yang dinyatakan dengan angka dan satuan matematis tertentu. Secara kualitas hunian bisa dikatakan sebagai perwujudan ruang interaksi manusia dengan semestanya (Norberg-Schulz, 1985: 247). Namun, sebetulnya pengertiannya bisa lebih luas lagi, yaitu ruang interaksi manusia dengan Pencipta alam semesta ini. Oleh sebab itu, ruang tidak bisa diartikan hanya yang terbentuk oleh batas fisik saja atau materi saja, namun justru sangat ditentukan oleh batas-batas non fisik seperti "rasa ruang" dari penghuni ruang tersebut. Ruang menjadi bermakna setelah terjadi suatu proses kehidupan manusia di dalamnya, karena "batas-batas" non fisik ditentukan oleh manusia yang berada di dalamnya. Membahas tentang rumah berarti membahas kebudayaan suatu masyarakat yang terepresentasi melalui ruang yang digunakan untuk berhuni. Dari berhunilah manusia mengejawantahkan dirinya sebagai makhluk sosial dan mempunyai struktur keluarga, baik secara 
vertikal maupun horisontal. Banyak sudut pandang yang dapat digunakan untuk mencermati bentuk yang tercipta.

Dari paparan di atas, dapat dipahami adanya keterkaitan antara pandangan hidup manusia dengan lingkungan binaan tempat tinggalnya. Begitu pula dengan Islam sebagai pandangan hidup setiap muslim. "Islamic beliefs shape the way Muslims build and use their built environment, " (Omer, 2009: 2). Pandangan hidup seorang muslim akan berpengaruh pada lingkungan tempat tinggalnya. Apabila tiap muslim benar-benar istiqomah dengan pandangan hidupnya, maka hablumminallah, hablumminannaas dan hablumminal'alam, akan tercermin dalam hunian mereka. Ketidakseimbangan dari ketiga aspek di atas tentu berdampak pada kerusakan akhlak, lingkungan alam bahkan lingkungan sosial.

Setiap perbaikan kualitas hubungan manusia dengan lingkungan alam dan lingkungan sosial, hendaknya tidak sekedar dibingkai oleh kebutuhan akan kelangsungan hidup manusia itu sendiri. Sebagai seorang muslim, seluruh usaha kebaikan harus dibingkai oleh niat yang benar dan lurus untuk beribadah kepada Allah SWT., sembari menjalankan misi-misi kekhalifahan manusia di muka bumi. Demikian juga, setiap perbaikan dalam kualitas hubungan-hubungan ini melalui perbaikan kualitas hunian, akan dinilai ibadah oleh Allah SWT.

\section{Hakikat Rumah bagi Seorang Muslim}

Islam tidak memberi arahan bagi muslim bagaimana cara membangun rumah, namun memerintahkan mereka bagaimana melaksanakan sejumlah anjuran secara langsung atau tidak langsung yang berhubungan dengan rumah dan fenomena perumahan. Beberapa anjuran itu adalah: privasi dari dunia luar, antar anggota keluarga, antara anggota keluarga dan pengunjung, menghormati hak-hak tamu dan pengunjung, menghormati hak-hak tetangga, hubungan antara pria dan wanita, implikasi melaksanakan ajaran agama, seperti kebersihan, hidup berdampingan secara damai dengan lingkungan alam, keselamatan, keamanan, rekreasi, kesopanan, tujuan Islam untuk melestarikan kehidupan, agama, mental dan kekuatan psikologis, keturunan dan kekayaan masyarakatnya (Omer, 2008: 491).

Setiap manusia mempunyai kapasitas untuk menjadi pemimpin, baik bagi diri sendiri maupun bagi orang lain seperti diriwayatkan oleh $\mathrm{HR}$ al Bukhari. Rumah merupakan tempat yang tepat untuk memulainya dengan menegakkan perintah dan menjauhi larangan Allah SWT, memulai setiap usaha mendekatkan diri, dan memperbaiki kualitas hubungan dengan Allah SWT. 
Begitu juga dengan keberadaan rumah yang digunakan sekaligus sebagai tempat kos bagi mahasiswa, di dalamnya akan terjadi pertemuan berbagai kepentingan yang mungkin saja mempunyai nilai yang berbeda dengan yang diajarkan sebelumnya. Akan terjadi percampuran nilai antara keluarga ibu kos dengan anak kos sebagai pendatang. Dalam hal ini, nilai-nilai yang sudah dipegang teguh oleh pemilik rumah akan semaksimal mungkin dipertahankan.

Perubahan nilai akan terjadi apabila terdapat aktivitas-aktivitas yang memungkinkan keduanya bertemu. Pengaturan privasi dan aksesibilitas, melalui penataan ruang dan pintu masuk, pemilik rumah berusaha meminimalisasi adanya persinggungan nilai-nilai tersebut. Privasi adalah konsep sentral yang menghubungkan antara ruang pribadi, teritori, dan perilaku sosial. Privasi merupakan batas-batas yang mengatur proses hubungan interpersonal yang dilakukan seseorang terhadap orang lain atau sekelompok orang dengan yang lainnya.

Berdasarkan nilai-nilai Islam terdapat beberapa anjuran dalam al Quran dan Hadits Nabi SAW tentang penataan dan hubungan antar ruang hunian rumah muslim (Junara, 2009: 48-54) yang di dalamnya terkait hak privasi muslim. Beberapa diantaranya adalah:

1. Menjaga privasi orang tua pada waktu tertentu.

Dalam al Quran, Allah SWT berfirman:

"Hai orang-orang beriman, hendaklah budak-budak (lelaki dan wanita) yang kamu miliki, dan orang-orang yang belum baligh di antara kamu, meminta izin kepada kamu tiga kali (dalam satu hari) yaitu sebelum sembahyang subuh, ketika kamu menanggalkan pakaian (luar)mu di tengah hari, dan sesudah sembahyang isya'...." (QS an Nur (24): 58-59).

Ayat tersebut menjelaskan tentang adab pergaulan di dalam rumah, dimana privasi orang tua harus benar-benar dijaga.

2. Memisahkan tempat atau ruang tidur bagi anak-anak.

"Suruhlah anak-anakmu sholat bila berumur tujuh tahun dan gunakanlah pukulan jika mereka sudah berumur sepuluh tahun dan pisahkan tempat tidur mereka" (HR Abu Dawud).

Salah satu hikmah dari hadits ini adalah menghindari penyimpangan jiwa yang mungkin terjadi akibat tampaknya aurat masing-masing.

3. Menjaga privasi penghuni terhadap tamu dan kerabat yang bukan mahram.

Nabi Muhammad SAW bersabda, "Seorang tamu yang masuk ke rumah suatu kaum, hendaklah duduk di tempat yang ditunjuk kaum itu, sebab mereka lebih mengenal tempat-tempat aurat rumah mereka" (HR ath Thabrani). Menjaga dan menutup aurat tetap diwajibkan apabila terdapat orang-orang yang bukan mahram di dalam rumah muslim. 
4. Ketentuan arah toilet di dalam bangunan.

Salah satu hadits yang dijadikan pedoman arah toilet bagi rumah muslim adalah, "Apabila kamu hendak buang air besar, maka janganlah kamu menghadap kiblat dan janganlah membelakanginya, baik ketika buang air kecil maupun buang air besar. Tetapi hendaklah kamu menghadap ke timur atau barat (selain arah kiblat)" (HR Bukhari-Muslim).

5. Ketentuan penataan tempat tidur.

Penataan tempat tidur seringkali dianjurkan untuk menghadapkan wajah ke arah kiblat, dengan posisi badan miring ke kanan. Anjuran untuk menghadapkan wajah ke arah kiblat berkaitan dengan keutamaan arah kiblat bagi berbagai kegiatan yang baik, seperti do'a, menuntut dan menyembelih binatang (al Hadrami, 2009: 353).

\section{Keseimbangan Antara Privasi dan Interaksi}

Berkenaan dengan penataan ruang hunian, dimana masyarakat kampung tinggal di lahan-lahan sempit, dengan sarana dan prasarana lingkungan yang minim, masyarakat berusaha menyiasati pengaturan ruang-ruang dalam huniannya untuk melakukan aktivitas spiritual sebagai bagian dari masyarakat muslim yang majemuk. Dalam Islam sesungguhnya terdapat keseimbangan yang paling sempurna dalam pengaturan hubungan manusia. Konsep hunian mengatur dengan sebaik-baiknya interaksi dan privasi antar manusia di dalam dan di luar rumah muslim.

Tidak ada ketertutupan yang total maupun keterbukaan yang mutlak yang melampaui batas-batas kepatutan. Ketertutupan yang total sering diidentikkan dengan individualitas dan ketidakpedulian. Hal ini mengakibatkan dampak yang buruk bagi lingkungan sekitarnya. Sedangkan keterbukaan yang mutlak juga tidak kalah buruknya bagi lingkungan sosial. Ajaran Islam, tidak melarang seseorang untuk mempersilakan orang lain masuk ke dalam rumahnya seperti menerima tamu, pembantu atau sanak keluarga yang lain. Namun, terdapat beberapa aturan syariat dan tuntunan adab yang harus dipenuhi dalam interaksi ini. Khalwat, atau berdua-duaan dengan lawan jenis yang bukan mahram merupakan salah satu larangan dalam Islam.

Konsep privasi dan interaksi dalam hunian seorang muslim memiliki keterkaitan erat dengan konsep aurat yang harus dilindungi atau ditutupi dari orang-orang yang bukan mahram. Perwujudan perlindungan terhadap aurat pada hunian muslim adalah dengan penerapan prinsip privasi, baik antar penghuni rumah maupun antara penghuni rumah dengan orang lain, di dalam 
maupun di sekitar hunian. Beberapa tuntunan al Quran dan al Hadits dalam hal privasi penghuni rumah diantaranya adalah sebagai berikut:

1. "Hai orang-orang yang beriman, janganlah kamu memasuki rumah yang bukan rumahmu sebelum meminta izin dan memberi salam kepada penghuninya. Yang demikian itu lebih baik bagimu, agar (selalu) ingat. Jika kamu tidak menemui seorangpun di dalamnya, maka janganlah kamu masuk sebelum kamu mendapat izin. Dan jika dikatakan kepadamu "Kembali (saja)lah", maka hendaklah kamu kembali.

2. "...Dan bukanlah kebajikan memasuki rumah-rumah dari belakangnya, akan tetapi kebajikan itu ialah kebajikan orang yang bertakwa. Dan masuklah ke rumah-rumah itu dari pintu-pintunya; dan bertakwalah kepada Allah agar kamu beruntung." (QS al Baqarah: 189).

3. "Jika salah seorang dari kalian meminta izin untuk masuk sebanyak tiga kali, dan ternyata dia tidak diizinkan, segeralah kembali pulang." (HR Bukhari-Muslim).

4. "Kalau ada seseorang mengintip rumahmu tanpa izin lalu kau melemparnya dengan batu sehingga matanya terluka, maka kau tidak berdosa." (HR Muslim).

5. "Seorang tamu yang masuk ke rumah suatu kaum hendaklah duduk di tempat yang ditunjuk kaum itu sebab mereka lebih mengenal tempattempat aurat mereka." (HR ath Thabrani).

Secara arsitektural, penerapan privasi di lingkungan hunian dapat dibedakan menjadi dua macam, yaitu (1) privasi rumah terhadap lingkungan sekitar, dan (2) privasi di dalam rumah itu sendiri. Privasi rumah terhadap lingkungan sekitar didasarkan pada prinsip batasan interaksi yang melibatkan penghuni dan lingkungan sosialnya. Sementara itu, privasi di dalam rumah didasarkan pada prinsip batasan interaksi yang melibatkan para penghuni rumah. Beberapa tuntunan interaksi antar penghuni rumah, sebagai berikut:

1. Privasi orang tua terhadap penghuni lainnya

2. Privasi antar anak

3. Privasi penghuni terhadap tamu dan kerabat yang buka mahram

4. Privasi tamu, kerabat dan pembantu yang bukan mahram.

Terdapat beberapa alternatif perancangan arsitektural dari penerapan konsep privasi di dalam dan di luar hunian muslim, antara lain:

1. Pemisahan zona. Terdapat batasan yang jelas antar zona dalam rumah tinggal. Ruang tamu dan beranda dapat dikategorikan sebagai ruang-ruang 
yang bersifat publik.

2. Penataan orientasi dan hubungan antar ruang. Beberapa ruang dapat dapat saja diletakkan berdampingan atau berdekatan, tanpa memiliki hubungan visual apapun satu sama lain. Hal ini dipengaruhi tingkat ketertutupan dan orientasi ruang.

3. Fleksibilitas pemanfaatan ruang. Untuk luas lahan yang terbatas dapat dirancang ruang-ruang yang multifungsi untuk tempat tinggal muslim. Ruang untuk mushola dapat digabung dengan ruang baca, beranda yang cukup luas dapat difungsikan juga ruang menerima tamu, bahkan ruang tamu dan ruang keluarga dapat "digabung" apabila terdapat aktivitas yang memerlukan ruangan yang lebih luas lagi.

4. Pemisahan bangunan. Jika lahan yang tersedia cukup luas, pemenuhan kebutuhan akan privasi dapat diwujudkan dengan pemisahan bangunan untuk keperluan publik dan privat.

5. Pemisahan akses keluar masuk. Jika lahan yang tersedia sempit, seperti kebanyakan rumah-rumah tinggal di kampung padat penduduk, pemenuhan kebutuhan privasi dapat digunakan melalui pemisahan akses.

\section{Gambaran Umum Wilayah Studi Kasus}

Kampung Ketawanggede Kota Malang merupakan salah satu permukiman yang khas karena letaknya berdekatan dengan sarana perguruan tinggi yang mempunyai keragaman wujud fisik hunian. Perkembangan bentuk rumah di kampung ini banyak dipengaruhi oleh perkembangan sosial dan ekonomi yang terjadi pada masyarakatnya. Bertambahnya penghuni, baik yang disebabkan faktor alamiah seperti kelahiran maupun faktor ekonomi seperti adanya usaha rumah kos merupakan hal yang jamak terjadi.

Kehidupan sosial ekonomi masyarakat di kampung ini awalnya sebagian besar berada pada tingkat ekonomi menengah ke bawah. Mereka hidup bersosialisasi dan berinteraksi dengan lingkungan fisik di sekitarnya dengan segala keterbatasan yang mereka punyai. Kehadiran beberapa perguruan tinggi di sekitar kampung ini kemudian mendorong sebagian masyarakat untuk melakukan perubahan pada rumah tinggal mereka dengan usaha rumah kos. Terjadinya interaksi antara pemilik rumah, anak kos dan lingkungan sekitar menjadikan terjadinya perubahan ruang. Perubahan tersebut bisa secara fisik ruang, sifat ruang maupun kegunaan ruang. Disinilah akan terjadi pergeseran fungsi-fungsi ruang dari privat-publik ataupun sebaliknya dari publik-privat. 


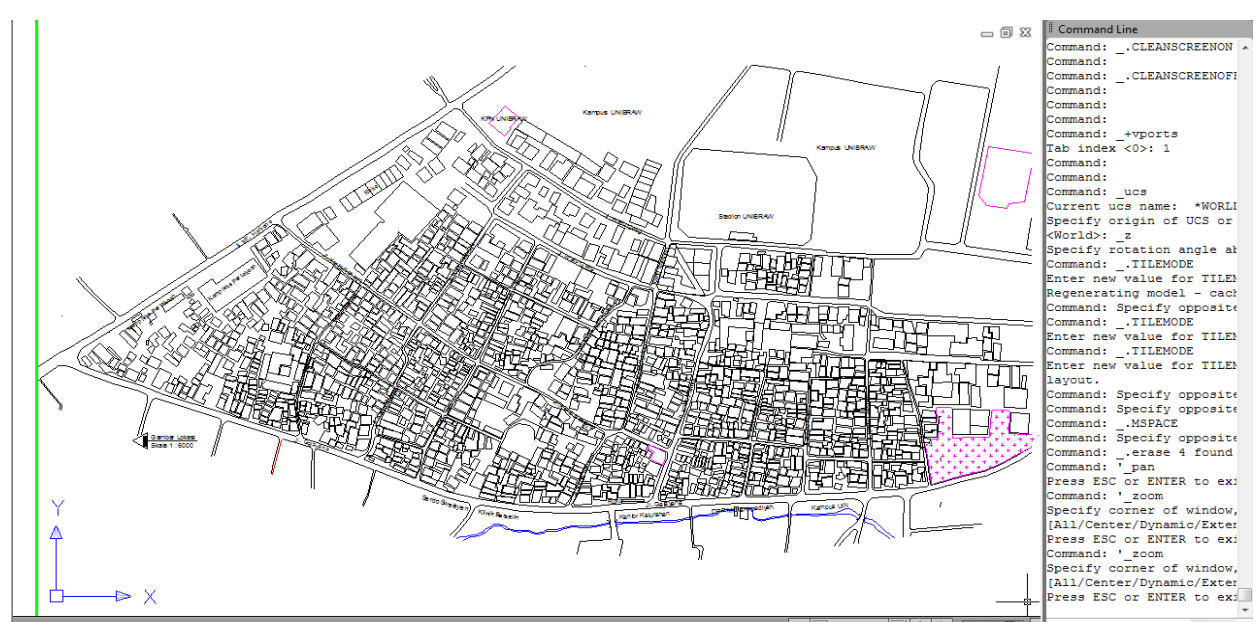

Gambar 1. Lokasi Penelitian (Hasil survey, 2011)

Dengan keterbatasan ruang yang ada, penduduk kampung berusaha mensiasati kebutuhan ruang, baik untuk kebutuhan privat maupun sosial yang dimanfaatkan secara optimal. Dari aktivitas yang biasa terjadi dalam rumah tangga dimana kegiatan yang ada merupakan suatu aktivitas domestik dan privat akan mengalami perubahan aktivitas yang terjadi dikarenakan hadirnya usaha pondokan yang mereka kelola maupun aktivitas sosial di masyarakat seperti arisan, pengajian, maupun aktivitas kemasyarakatan yang lain. Ruangruang yang tadinya tertutup bagi orang lain akan menjadi terbuka karena hadirnya orang lain diluar anggota keluarga tersebut. Penelitian ini berusaha mengetahui bagaimana masyarakat berusaha menyiasati adanya perubahan aktivitas di dalam rumahnya ditinjau dari nilai-nilai as Sunah sebagai bagian dari masyarakat muslim.

Ditinjau dari konsep interaksi dan privasi dalam Islam, bahwa pertimbangan akan privasi penghuni merupakan salah satu cara pengaturan ruang hunian. Zona publik terdapat pada ruang tamu, beranda dan paviliun. Zona privat terdapat pada ruang tidur orang tua dan ruang tidur anak, termasuk kamarkamar kos. Zona semi privat terdapat pada ruang keluarga, kamar mandi dan dapur. Sedangkan dapur termasuk dalam sarana penunjang.

Untuk menentukan ruang-ruang menurut hierarki privat-publik serta mempermudah memberi gambaran tentang ruang-ruang berdasarkan aksesibilitas penghuninya, maka ruang-ruang dalam rumah hunian akan dianalisis menurut standar ruang-ruang yang biasanya ada dalam rumah hunian. yaitu adanya halaman, beranda, ruang tamu, ruang keluarga, ruang makan, ruang tidur, 
serta ruang-ruang penunjang seperti dapur, $\mathrm{km} / \mathrm{wc}$, tempat jemur, dll.

Tabel 1. Pembagian ruang secara umum berdasarkan sifat ruang

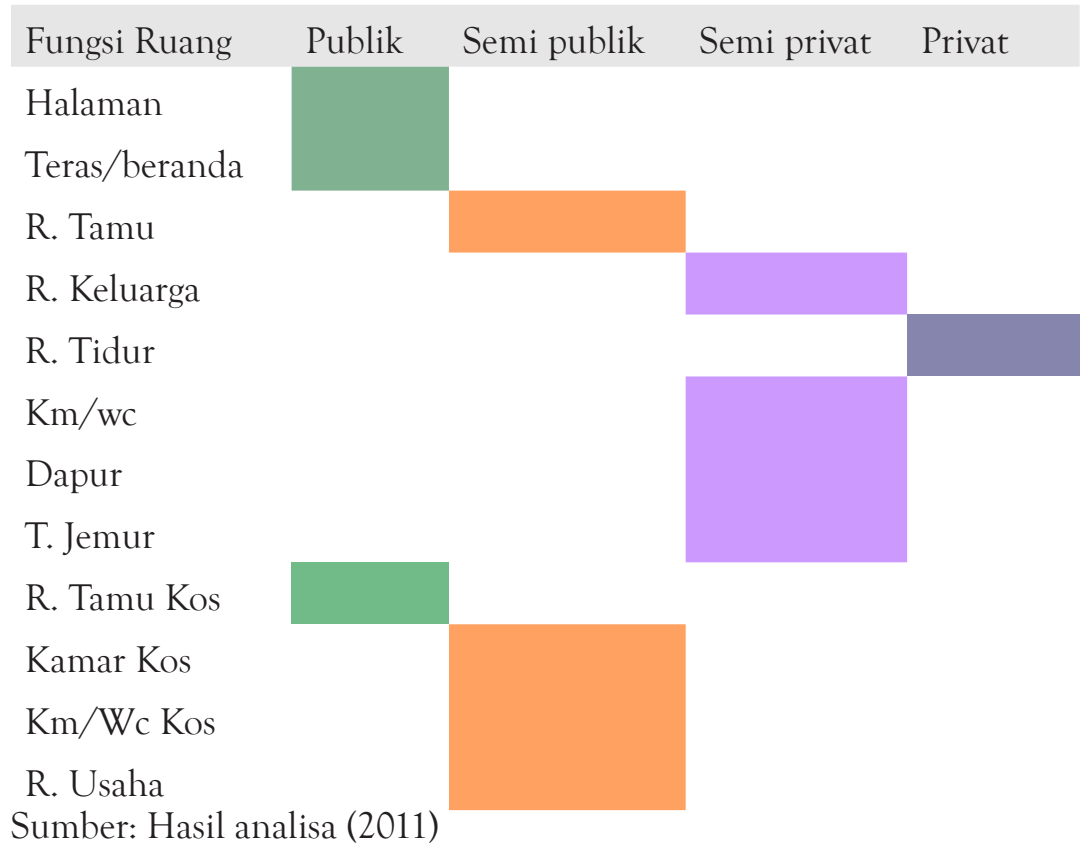

Analisa Rumah Hunian dan Aksesibilitas

Selain rumah hunian dengan usaha pondokan mahasiswa, akasesibilitas ruang juga digunakan sebagai salah satu kriteria dalam menentukan sampel dari rumah-rumah yang diteliti. Pemisahan maupun penyatuan akses keluarmasuk ke dalam hunian merupakan salah satu faktor terjadinya tidaknya interaksi antara penghuni rumah dengan pihak lain di sekitarnya. Dalam hal ini, rumah dibedakan menurut aksesibilitas yang terjadi di dalam rumah hunian tersebut, antara aksesibilitas pemilik rumah dan penghuni kamar kosnya maupun aksesibilitas antara penghuni rumah dengan pihak di luar rumahnya, seperti tamu, tetangga maupun kerabat. Dari data yang diperoleh dengan membandingkan antara jumlah ruang pada awal rumah ditempati dengan jumlah ruang pada hasil penelitian terlihat bahwa rumah mengalami perkembangan yang pesat pada jumlah ruang yang dimilikinya seperti ruang keluarga, ruang tidur, kamar kos, km/wc, dapur, dan ruang jemur. Dari sini didapatkan kriteria, yaitu: 


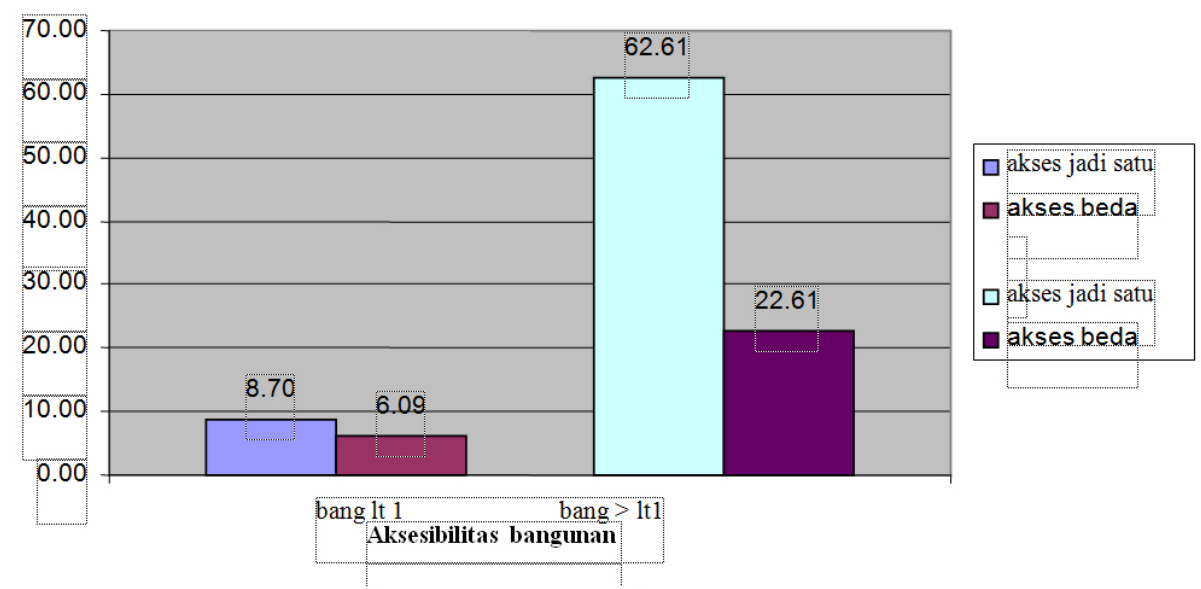

Gambar 2. Grafik aksesibilitas bangunan.

Sumber: Hasil survey (2011)

Dari data yang diperoleh dengan membandingkan antara jumlah ruang pada awal rumah ditempati dengan jumlah ruang pada hasil penelitian (Gambar 2), terlihat bahwa rumah mengalami perkembangan yang pesat pada jumlah ruang yang dimilikinya seperti ruang keluarga, ruang tidur, kamar kos, km/wc, dapur, dan ruang jemur. Dalam hal ini, rumah dibedakan menurut aksesibilitas yang terjadi di dalam rumah pondokan tersebut, antara aksesibilitas pemilik rumah dan penghuni kamar kosnya. Dari sini didapatkan kriteria, yaitu:

1. Rumah hunian berlantai satu dengan aksesibilitas yang sama.

2. Rumah hunian berlantai satu dengan aksesibilitas yang berbeda.

3. Rumah hunian bertingkat dengan aksesibilitas yang sama.

4. Rumah hunian bertingkat dengan aksesibilitas yang berbeda.

Berdasarkan tipe-tipe hunian yang telah dibahas sebelumnya, maka hasil analisa pada rumah hunian di sini dapat dilihat dari uraian dibawah ini: 
1. Responden 1 (Rumah Hunian Berlantai Satu dengan Aksesibilitas Sama)
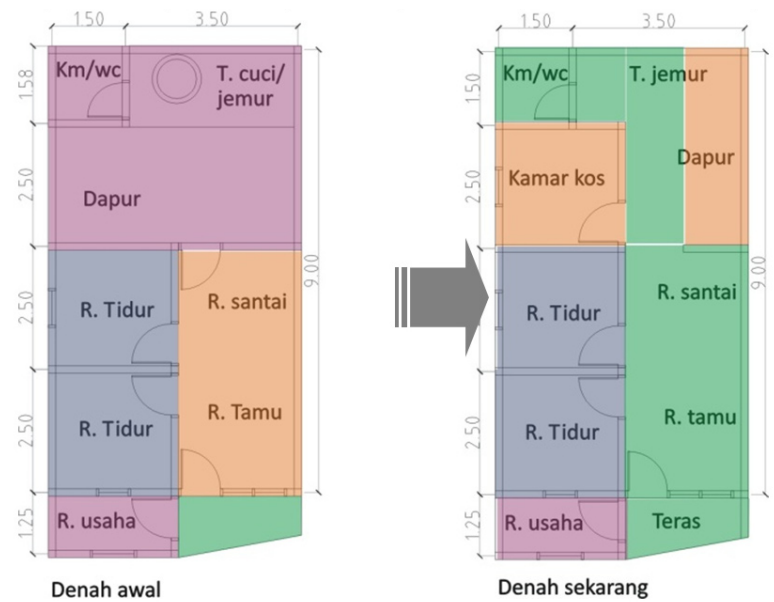

Gambar 3. Rumah hunian satu lantai dengan aksesibilitas sama (Sumber: Hasil survey dan analisa, 2011)

Tabel 2. Perubahan Ruang

\begin{tabular}{|c|c|c|c|}
\hline \multicolumn{2}{|c|}{ Perubahan } & \multicolumn{2}{|c|}{ Sifat Perubahan } \\
\hline Dulu & Sekarang & Dulu & Sekarang \\
\hline Teras & Teras & publik & publik \\
\hline R. tamu & R. tamu & semi publik & publik \\
\hline R. keluarga & R. keluarga & semi privat & semi privat \\
\hline R. Tidur & R. Tidur & privat & privat \\
\hline Dapur & Kamar kos & semi privat & semi publik \\
\hline $\mathrm{Km} / \mathrm{wc}$ & T. cuci & semi privat & publik \\
\hline T. jemur & T. jemur & semi privat & semi privat \\
\hline R. tamu kos & R. tamu & publik & publik \\
\hline
\end{tabular}

Sumber: Hasil analisis (2011)

Rumah mengalami renovasi dengan menambah satu kamar sebagai tempat kos. Terjadi pergeseran fungsi ruang-ruang dimana ruang semi privat yang sebelumnya berfungsi sebagai dapur berubah menjadi ruang privat bagi penghuni kamar kos. Dari situasi ini maka ruang tamu dan ruang keluarga sebagai area semi publik dan semi privat akan berubah menjadi area publik dikarenakan fungsinya berubah sebagai area sirkulasi bagi penghuni kamar kos. 
Dari penerapan nilai-nilai as Sunah, privasi antara pemilik rumah, anak kos dan pihak luar seperti tamu, tetangga maupun kerabat kurang dapat terjaga dikarenakan arah hadap kamar tidur yang langsung ke area publik. Namun demikian, penghuni tidak merasa terganggu privasinya dan cukup merasa nyaman dengan kondisi ruang tidurnya. Apabila ada kegiatan sosial seperti arisan dan pengajian, ruang keluarga akan berfungsi juga sebagai ruang publik bagi para tamu. Dalam kondisi seperti itu penghuni akan menahan diri untuk tidak keluar masuk ke area privatnya. Untuk kegiatan beribadah mereka memanfaatkan ruang tidur sekaligus sebagai tempat sholat. Interaksi dengan anak kos juga tidak mempengaruhi privasi penghuni karena sudah menganggap anak kos seperti anaknya sendiri.

2. Responden 2 (Rumah Hunian Berlantai Satu dengan Aksesibilitas Berbeda)

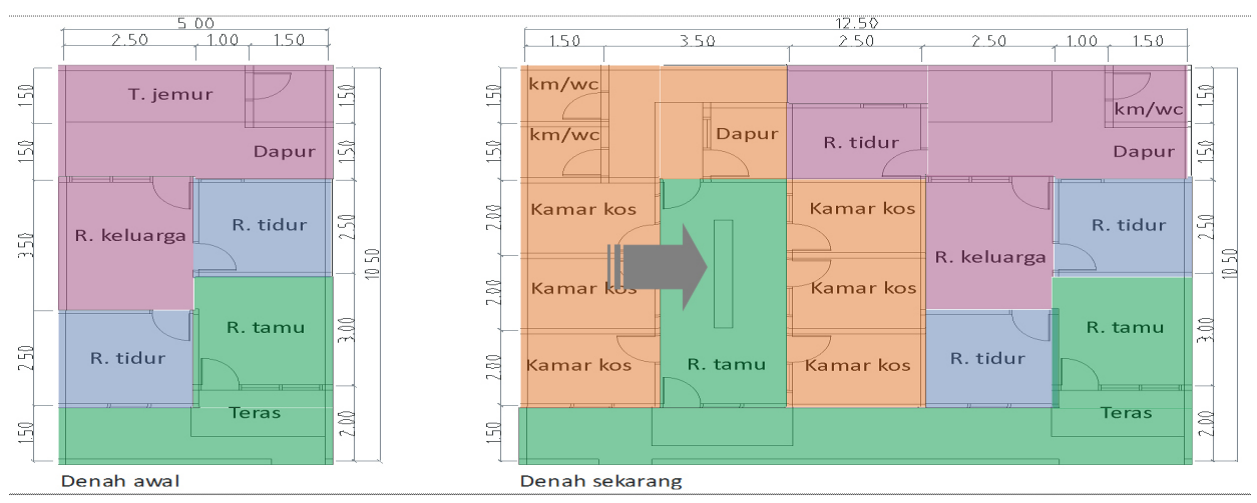

Gambar 4. Rumah Hunian Satu Lantai dengan Aksesibilitas Berbeda (Sumber: Hasil survey dan analisa, 2011)

Tabel 3. Perubahan Ruang

\begin{tabular}{llll}
\multicolumn{1}{c}{ Perubahan } & \multicolumn{2}{c}{ Sifat Perubahan } \\
Dulu & Sekarang & \multicolumn{1}{c}{ Dulu } & \multicolumn{1}{c}{ Sekarang } \\
Teras & Teras & publik & publik \\
R. tamu & R. tamu & semi publik & publik \\
R. keluarga & R. keluarga & Semi privat & Semi privat \\
R. Tidur & R. Tidur & privat & privat \\
Dapur - kamar kos & Dapur & semi privat & semi privat \\
Km/wc - t. cuci & Km/wc & semi privat & semi privat \\
T. jemur & T. jemur & semi privat & semi privat
\end{tabular}

Sumber: Hasil Analisa (2011) 
Rumah pada awal ditempati berfungsi sebagai tempat tinggal keluarga. Ruang-ruang yang ada terdiri dari 2 kamar tidur, teras, ruang tamu, ruang keluarga, dapur dan kamar mandi. Ruang publik disini adalah teras, untuk menerima tamu yang kurang dikenal, sedangkan ruang tamu dan ruang keluarga lebih bersifat semi publik. Ruang-ruang tidur merupakan area privat dan area servis yang terdiri dari dapur dan kamar mandi lebih bersifat semi privat.

Penerapan nilai-nilai as Sunah pada penataan ruang cukup berhasil. Hal ini dapat dilihat pada:

a. Aksesibilitas antara penghuni dan anak kos dibuat berbeda sehingga interaksi antar pemilik rumah, anak kos dan pihak luar cukup terjaga.

b. Ruang tamu meskipun berdekatan dengan ruang tidur, namun penghuni cukup mendapatkan privasi karena arah hadap pintu ke dalam/ruang keluarga.

c. Kegiatan sosial seperti arisan dan pengajian cukup dilaksanakan di ruang tamu sampai dengan halaman.

d. Untuk kegiatan beribadah mereka memanfaatkan ruang tidur sekaligus sebagai tempat sholat.

3. Responden 3 (Rumah Hunian Bertingkat dengan Aksesibilitas yang Sama)

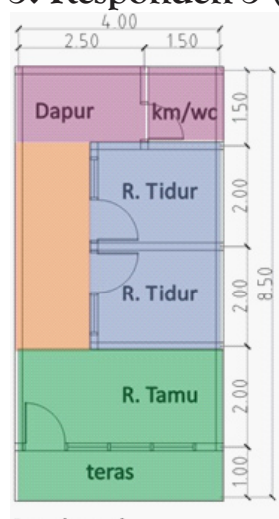

Denah awal

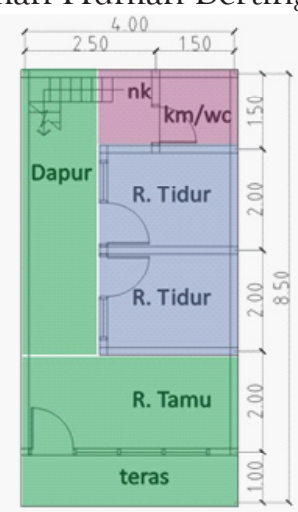

Denah lantai 1

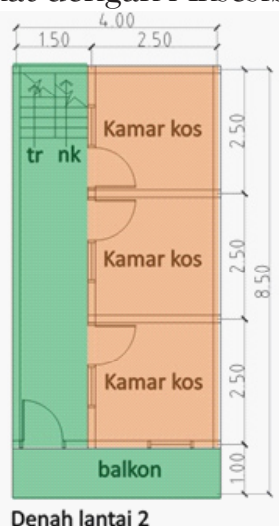

Denah lantai 2

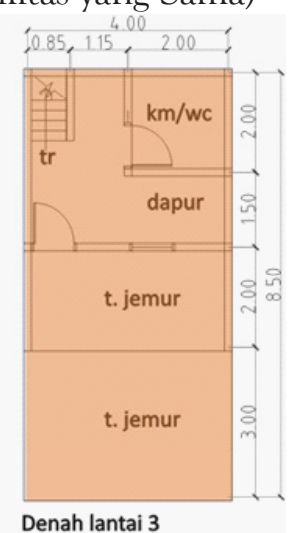

Denah lantai 3

Gambar 5. Rumah hunian bertingkat dengan aksesibilitas yang sama (Sumber: Hasil survey dan analisa, 2011) 
Tabel 4. Perubahan Ruang

\begin{tabular}{llll}
\multicolumn{2}{c}{ Perubahan } & \multicolumn{2}{c}{ Sifat Perubahan } \\
Dulu & Sekarang & \multicolumn{1}{c}{ Dulu } & \multicolumn{1}{c}{ Sekarang } \\
Teras & Teras & publik & publik \\
R. tamu & R. tamu & semi publik & publik \\
R. keluarga & Sirkulasi & Semi publik & publik \\
R. Tidur & R. Tidur & Semi privat & publik \\
Dapur & Sirkulasi & semi privat & Publik \\
Km/wc - t. cuci & Km/wc & semi privat & semi privat
\end{tabular}

Sumber: Hasil analisa (2011)

Pada awal ditempati, rumah hunian terdiri dari 2 ruang tidur, dapur, kamar mandi, ruang tamu dan teras. Fungsi rumah hanya sebagai rumah tinggal biasa. Area yang bersifat publik adalah teras dan ruang tamu. Area semi publik mencakup ruang keluarga di depan ruang-ruang tidur, sedangkan dapur dan kamar mandi sebagai area servis termasuk area semi privat. Yang terakhir adalah ruang-ruang tidur yang merupakan area privat. Setelah berubah fungsi menjadi rumah pondokan, maka terdapat perubahan sifat ruang diantaranya ruang di depan kamar dan dapur yang berubah menjadi jalur sirkulasi/ publik.

Penerapan nilai-nilai as-Sunah pada penataan ruang di rumah ini tidak terlihat. Ruang tidur meskipun cukup terjaga privasinya dari ruang tamu, namun di depan ruang tidur berubah menjadi ruang publik. Hal ini dikarenakan berubahnya fungsi di lantai 2 dan 3 sebagai tempat kos sehingga ruang di depan ruang tidur menjadi jalur sirkulasi bagi anak kos dan mungkin juga teman-temannya sebagai pihak luar. Untuk melakukan aktivitas peribadatan, penghuni memanfaatkan ruang tidur sebagai tempat sholat. Aktivitas sosial kemasyarakatan memanfaatkan ruang tamu, teras dan jalan di depan rumah. 
Perubahan

Dulu

Teras

R. tamu

R. keluarga

R. Tidur
4. Responden 4 (Rumah Hunian Bertingkat dengan Aksesibilitas yang Berbeda)
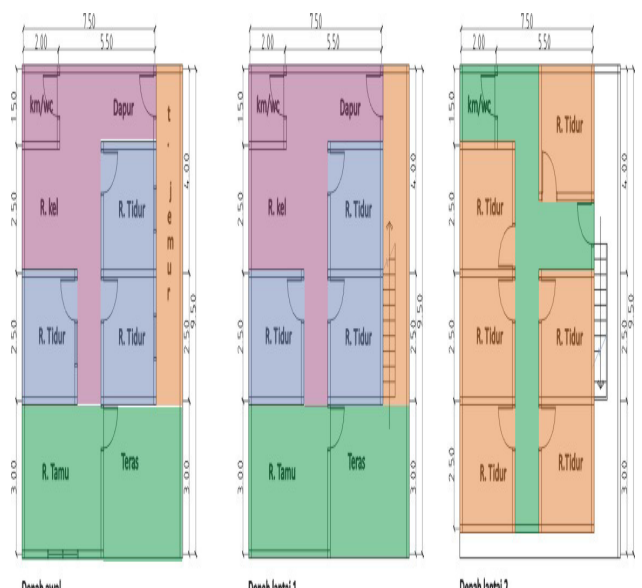

Denalawa

Denthentantit!

Detah|ania|?

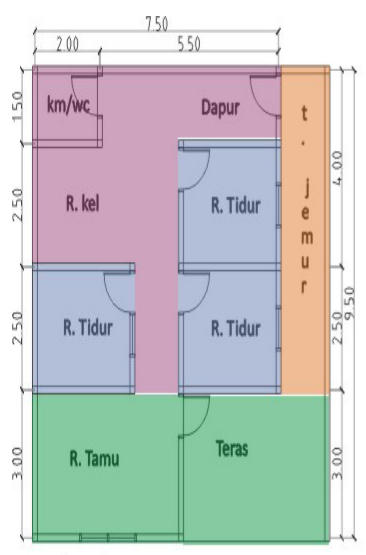

Denah awal

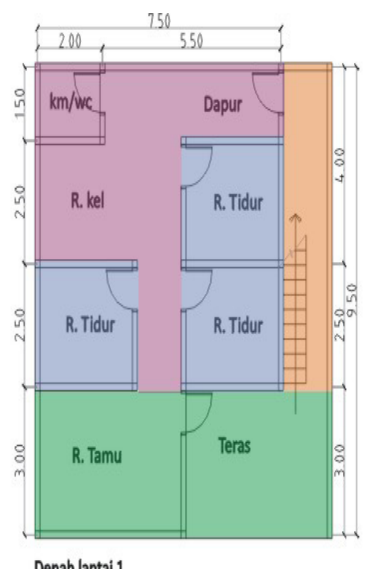

Denah lantai 1
Denah lantai 2

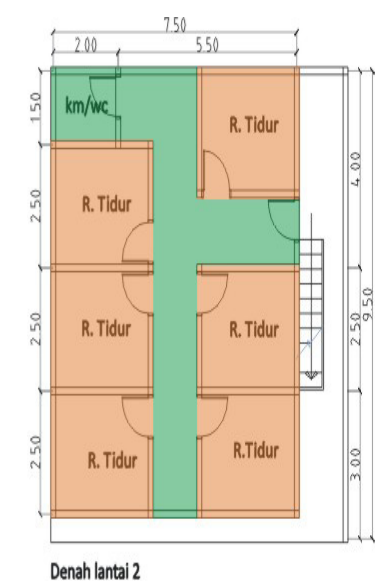

Gambar 6. Rumah hunian bertingkat dengan aksesibilitas yang berbeda (Sumber: Hasil survey dan analisa, 2011)

Tabel 5. Perubahan Ruang

\section{Ruang}




$\begin{array}{llll}\text { Dapur }- \text { kamar kos } & \text { Dapur } & \text { semi privat } & \text { semi privat } \\ \text { Km } / \text { we }- \text { t. cuci } & \mathrm{Km} / \mathrm{wc} & \text { semi privat } & \text { semivat } \\ \text { T. jemur } & \text { T. jemur } & \text { semi publik } & \text { semi publik }\end{array}$

Pada awalnya hunian ini merupakan rumah tinggal biasa. Perkembangan selanjutnya, rumah dijadikan usaha pondokan mahasiswa dengan menambah 5 kamar kos di lantai 2 dan 2 kamar di lantai 3 disertai penambahan 2 kamar mandi serta dapur. Disini tidak terjadi pergeseran ruang privat-publik dari denah awal maupun pada denah yang sekarang.

Penerapan nilai-nilai as Sunah pada penataan ruang cukup berhasil. Hal ini dapat dilihat pada:

1. Aksesibilitas antara penghuni dan anak kos dibuat berbeda sehingga interaksi antar pemilik rumah, anak kos dan pihak luar cukup terjaga. Interaksi antar pemilik rumah, anak kos dan pihak luar (tamu, tetangga maupun kerabat) cukup terjadi di ruang tamu. Terdapat akses bagi pemilik rumah menuju ke tempat jemur di lantai 3 yang melewati tempat kos..

2. Ruang tamu meskipun berdekatan dengan ruang tidur, namun penghuni cukup mendapatkan privasi karena arah hadap pintu ke dalam/ruang keluarga.

3. Kegiatan sosial seperti arisan dan pengajian cukup dilaksanakan di ruang tamu sampai dengan halaman.

4. Untuk kegiatan beribadah mereka memanfaatkan ruang tidur sekaligus sebagai tempat sholat.

\section{Simpulan}

Kesimpulan dari hasil analisa sebelumnya bahwa bangunan rumah dengan aksesibilitas yang berbeda, jelas tersegmentasi melalui penyelesaian arsitektural. Penempatan pintu masuk yang berbeda, serta tidak adanya akses yang sama di dalam rumah hunian maupun rumah kos menjadikan tidak bertemunya aktivitas masing-masing penghuninya di dalam bangunan rumah tersebut. Hal ini tidak akan mempengaruhi privasi dari masing-masing penghuni secara fisik. Dilihat dari nilai-nilai as Sunah, hunian tersebut cukup berhasil menjaga privasi penghuninya, baik dari aktivitas yang ada di dalam hunian maupun yang berasal dari luar seperti adanya aktivitas anak kos dan lingkungan sekitarnya.

Sedangkan bangunan rumah dengan aksesibilitas sama, kemungkinan 
bertemunya beberapa aktivitas yang berbeda antara pemilik rumah dan penghuni kamar kos sangat besar. Dipandang dari nilai-nilai as Sunah, privasi penghuni akan terganggu. Akan terjadi pergeseran hierarki ruang privat-publik, yang akan mempengaruhi sifat ruang dan privasi penghuninya.Untuk menyelesaikannya, ada beberapa saran bagi pengaturan zona ruangnya. Zona publik di dalam rumah harus mempunyai batasan yang jelas dengan zona privat seperti ruang tidur dan ruang keluarga. Kejelasan zona dapat dicapai melalui orientasi/arah hadap ruang, pemberian pembatas yang masif dan fleksibel maupun dengan pengaturan jarak.

\section{Daftar Pustaka}

Bawole, Paulus. 2001. Karakteristik Ruang pada Arsitektur Kampung Kota”. Di dalam Seminar Nasional Psikologi Ruang dalam Arsitektur. Pasca Sarjana Universitas Diponegoro. Semarang.

Junara, Nunik dan Putrie, Yulia, Eka. 2009. Rumah Ramah Lingkungan. UIN Press. Malang.

Norberg-Schulz, C. 1985. The Concept of Dwelling. Rizzoli International Publication. New York.

Omer, Spahic. 2008. Towards Understanding Islamic Architecture. Islamic Studies. Volume 47. Nomor 4: 483-510.IIU. Islamabad. Pakistan.

diunduh dari http://search.proquest.com/docview/288224871?accountid= 31562

Omer, Spahic. 2009. The History and The Character of The Islamic Built Environment. Arah Publications. Sdn. Bhd. Selangor. Malaysia. 